\title{
JARAK, DURASI, DAN KELUHAN KELELAHAN MATA DALAM PENGGUNAAN GADGET CIVITAS AKADEMIKA STIKES DHARMA HUSADA BANDUNG TAHUN 2020
}

\author{
Venada Nasyahtadila $^{1)}$, Edi Djunaedi ${ }^{2)}$, Suparni $^{3)}$, Dwi Sekar Laras ${ }^{4)}$ \\ ${ }^{1,2,4}$ Program Studi Diploma Tiga Refraksi Optisi, STIKes Dharma Husada Bandung \\ ${ }^{3}$ Program Studi Sarjana Kesehatam Masyarakat, STIKes Dharma Husada Bandung \\ nsuparni@stikesdhb.ac.id
}

\begin{abstract}
Abstrak
Kesehatan mata sangatlah penting karena penglihatan tidak dapat digantikan dengan apapun, maka mata memerlukan pemeriksaan dan perawatan secara teratur. Penggunaan gadget pada masa sekarang sering kali digunakan untuk bermain games, interaksi social media, dan nonton video/film. Membiarkan mata berinteraksi dengan gadget dengan durasi waktu yang lama akan menimbulkan risiko gangguan refraksi miopia, dampak lainnya akan mengalami kelelahan mata, pandangan kabur hingga sakit kepala yang muncul saat menggunakan gadget dengan durasi yang lama, hal inilah yang menyebabkan mata kering (Handrawan, 2014). Untuk mengetahui Durasi Jarak dan Keluhan Kelelahan Mata yang ada pada pengguna gadget, tablet, atau laptop di Civitas Akademika STIKes Dharma Husada Bandung. Melalui pengisian kuesioner. Penelitian ini menggunakan metode survei deskriptif, dengan pendekatan cross sectional. Teknik pengambilan sampel adalah teknik purposive sampling dengan jumlah 258 responden. Penelitian ini dilakukan pada bulan Juli di Kampus STIKes Dharma Husada Bandung. Total sampel pada penelitian ini sebanyak 258 orang. Pada tabel distribusi Jarak, Durasi, dan Keluhan Kelelahan mata, diperoleh 93 orang (36\%) menggunakan Gadget dengan jarak 20cm. sebanyak 138 orang (53\%) menggunakan gadget dengan durasi >5 jam/Hari, dan sebanyak 236 orang (93\%) mengalami Keluhan kelelahan mata. Pengetahuan penggunaan jarak dan durasi pada Civitas STIKes Dharma Husada Bandung masih kurang sehingga masih banyak yang mengalami keluhan kelelahan mata.
\end{abstract}

Kata Kunci : Durasi, Gadget, Jarak, Keluhan Kelelahan Mata

\section{PENDAHULUAN}

Kesehatan mata sangatlah penting

karena penglihatan tidak dapat digantikan dengan apapun, maka mata memerlukan pemeriksaan dan perawatan secara teratur (Deddy dkk, 2009). Mata adalah salah satu indera yang penting bagi manusia, melalui mata manusia menyerap informasi visual yang digunakan untuk melaksanakan berbagai kegiatan. Namun gangguan terhadap penglihatan banyak terjadi, mulai dari gangguan ringan hingga gangguan yang berat yang dapat mengakibatkan kebutaan (Pusdatin Kemenkes RI, 2014).

Hasil penelitian sebuah lembaga riset menyebutkan bahwa Indonesia berada di peringkat kelima dalam daftar penggunaan gadget terbesar di dunia dengan pengguna aktif sebanyak 47 juta atau sekitar 14\% dari seluruh total pengguna ponsel (Dediu,2013). gadget tidak hanya sekedar dijadikan media hiburan semata tetapi dengan aplikasi yang terus diperbaharui gadget wajib digunakan oleh orang-orang yang memiliki kepentingan bisnis, 
atau keperluan pengerjaan tugas kuliah dan kantor.

Penggunaan gadget pada masa sekarang sering kali digunakan untuk bermain games, interaksi social media, dan nonton video/film. Membiarkan mata berinteraksi dengan gadget dengan durasi waktu yang lama akan menimbulkan risiko gangguan refraksi miopia, dampak lainnya akan mengalami kelelahan mata, pandangan kabur hingga sakit kepala yang muncul saat menggunakan gadget dengan durasi yang lama, hal inilah yang menyebabkan mata kering (Handrawan, 2014).

Gadget merupakan sumber utama gelombang elektromagnetik dan dapat berdampak pada kesehatan. Efek lain pada penggunaan gadget adalah sakit pada ekstremitas atas, leher dan punggung, didapatkan juga bahwa pengguna merasa tidak nyaman minimal satu dari lokasi di atas. Selain itu, kecenderungan masyarakat untuk menggunakan gadget dan tablet dengan tidak memperhatikan kesehatan mata dapat menimbulkan berbagai masalah kesehatan mata. Menurut penelitian dari The Vision Council tahun 2014 digital device yang sering digunakan adalah smartphone dan keluhan yang muncul paling besar persentasenya adalah eyestrain (Miakotko, 2017;Visioncouncil, 2013).

Eyestrain atau kelelahan mata juga disebut astenopia, terjadi pada saat mata terlalu lelah karena digunakan terlalu lama atau terlalu Jurnal Penelitian Kesehatan STIKes Dharma Husada Bandung 


\section{Identifikasi Masalah}

Sejak Maret 2020, pandemi virus corona (Covid-19) melanda Indonesia, pemerintah meminta masyarakatnya untuk mengurangi aktivitas di luar rumah. Sebagian besar kegiatan dilakukan melalui daring alias melalui online. Mulai belajar dari rumah hingga bekerja dari rumah atau work from home (WFH). Sehingga ini menyebabkan konsumsi penggunaan gadget pada masyarakat mulai mengalami peningkatan.

Hampir setiap waktu manusia tidak bisa terlepas dari gadget. Apalagi saat ini gadget dilengkapi dengan fitur canggih di dalamnya. Bukan hanya alat komunikasi, melainkan telah berkembang menjadi alat dengan fungsi lainnya, seperti media hiburan, media edukasi, media bisnis dan sebagainya. Menggunakan gadget melebihi batas waktu berkaitan pula dengan durasi paparan radiasi yang diterima oleh tubuh. Radiasi merupakan energi yang ditransmisikan, dikeluarkan atau diabsorbsi dalam bentuk partikel energi atau gelombang elektromagnetik. Lamanya radiasi yang menyinari tubuh khususnya mata walaupun dengan intensitas yang rendah akan tetapi dalam jangka waktu lama dapat menyebabkan gangguan fisiologis (Mangoenprasodjo, 2005).

Screen time didefinisikan sebagai durasi waktu yang digunakan untuk melakukan aktifitas di depan layar kaca media elektronik tanpa melakukan aktifitas olahraga misalnya duduk menonton televisi atau video, bermain komputer, maupun bermain permainan video. Jurnal Penelitian Kesehatan STIKes Dharma Husada Bandung
Screen time berdasarkan klasifikasi yaitu >2 jam/hari dan $\_$jam/hari , siswa-siswi memiliki screen based activity $>2$ jam/hari yang tinggi yaitu $80 \%$, hal ini menunjukkan bahwa sangat banyak aktifitas yang dilakukan anak-anak di depan layar >2jam/hari (Porotu'o, dkk, 2014).

Pada umumnya, jarak penggunaan gadget dan e-book kurang lebih adalah $30 \mathrm{~cm}$. Penelitian Babekova tahun 2011 menjelaskan bahwa rata-rata jarak penggunaan gadget berjarak 36,2 cm (Babekova et all 2011). Pada penelitian Long gejala keluhan kelelahan mata setelah membaca atau melihat melalui gadget selama 60 menit dan jarak rata-rata penggunaan gadget adalah 29,2 $\mathrm{cm}$ akan memperbesar timbulnya keluhan (Long et all, 2017).

\section{METODE PENELITIAN}

Konsep adalah suatu abstraksi yang dibentuk dengan menggeneralisasikan sesuatu pengertian. Oleh sebab itu, konsep tidak dapat diukur dan diamati secara langsung. Agar dapat diamati dan dapat diukur, maka konsep tersebut harus dijabarkan ke dalam variable-variabel. Kerangka konsep penelitian adalah suatu uraian dan visualisasi hubungan atau kaitan antara konsep satu terhadap konsep yang lainnya, atau antara variable yang satu dengan variable yang lain dari masalah yang ingin diteliti. (Notoadmodjo,2012).

Pada tujuan penelitian ini peneliti akan meneliti suatu permasalahan yaitu Jarak, Durasi, dan Keluhan Kelelahan Mata dalam 
Penggunaan Gadget Civitas STIKes Dharma Husada Bandung.

\section{A. Definisi Operasional}

Definisi operasional adalah suatu definisi yang diberikan kepada suatu variable atau memberikan suatu operasional yang diperlukan untuk mengukur variabel penelitian.
Karakteristik yang dapat diamati (diukur) merupakan kunci drai definisi operasional. Definisi operasional adalah uraian tentang batasan variabel yang dimaksud, atau tentang yang diukur oleh variabel yang bersangkutan (Notoatmodjo, 2010).

Tabel 1. Definisi Operasional

\begin{tabular}{|c|c|c|c|c|}
\hline Variabel & $\begin{array}{c}\text { Definisi } \\
\text { Operasional }\end{array}$ & $\begin{array}{l}\text { Alat } \\
\text { ukur }\end{array}$ & Hasil Ukur & Skala \\
\hline $\begin{array}{l}\text { Jarak, Durasi dan } \\
\text { Keluhan kelelahan } \\
\text { mata }\end{array}$ & $\begin{array}{l}\text { Mengetahui mengenai sesuatu } \\
\text { tentang jarak } \\
\text { durasi penggunaan gadget dan } \\
\text { keluhan kelelahan mata Civitas } \\
\text { Akademika STIKes Dharma } \\
\text { Husada Bandung : } \\
\text { 1. Jarak pandang saat } \\
\text { menggunakan gadget } \\
\text { yang benar dan aman. } \\
\text { 2. Durasi ketika menatap } \\
\text { layar gadget. } \\
\text { 3. Keluhan Kelelahan Mata. }\end{array}$ & $\begin{array}{l}\text { Pengisian } \\
\text { kuesioner }\end{array}$ & $\begin{array}{l}\text { 1. Jarak penggunaan } \\
\text { gadget } 20 \mathrm{~cm} \\
\text { 2. Jarak penggunaan } \\
\text { laptop dan tablet } \\
\text { 30cm } \\
\text { 3. Durasi penggunaan } \\
\text { gadget }>5 \text { jam } \\
\text { 4. Durasi penggunaan } \\
\text { laptop dan tablet }>3 \text { - } \\
\text { 5jam } \\
\text { 3. Ada keluhan } \\
\text { kelelahan mata }\end{array}$ & Ordinal \\
\hline
\end{tabular}

\section{B. Variabel}

Variabel yang digunakan dalam penelitian adalah Jarak, Durasi, dan Keluhan Kelelahan mata.

\section{Jenis Penelitian}

Berdasarkan permasalahan dan tujuan yang akan dicapai maka penelitian ini menggunakan metode deskriptif yaitu suatu metode penelitian yang digunakan dengan tujuan utama mengetahui suatu keadaan secara objektif.

Jurnal Penelitian Kesehatan STIKes Dharma Husada Bandung
Pengumpulan data dalam rancangan ini termasuk dalam jenis kuantitatif yaitu, penyajian data dalam bentuk angka yang dapat dihitung dengan system matematik dan dalam pengolahan data dilakukan dengan menggunakan rumus-rumus statistik.

\section{Metode Pengumpulan Data}

a. Metode pengumpulan data yang digunakan dalam penelitian ini adalah menggunakan metode pengisian 
kuesioner yang dilakukan secara online melalui google form yang disebarkan. Peneliti menggunakan 258 responden sebagai sampel.

b. Peneliti akan melakukan proses pengolahan dan Analisa data.

\section{HASIL DAN PEMBAHASAN}

\section{A. Hasil}

Gambaran Lokasi Penelitian Kampus STIKes Dharma Husada Bandung berlokasi di Jalan Terusan Jakarta No. 75 Antapani Bandung. Namun hingga saat ini,Yayasan Purna Dharma Husada Bandung terus mengembangkan kampus sehingga saat ini memiliki 2 lokasi kampus yaitu, Kampus I di jalan terusan Jakarta No 71-75 dan Kampus II di Jalan Cingised. Di lokasi kampus II kini telah dibangun gedung kampus permanen 3 tingkat yang akan digunakan sebagai cikalbakal Kampus Terpadu STIKes Dharma Husada Bandung.

\section{Karakteristik Responden}

Berdasarkan hasil penelitian yang dilakukan dikampus STIKes Dharma Husada Bandung dengan jumlah reponden sebanyak 258 responden memiliki karakteristik sebagai berikut :

\section{a. Jenis Kelamin}

\section{Tabel 2}

Distribusi Jenis Kelamin Responden di Kampus STIKes Dharma Husada Tahun 2020

\begin{tabular}{lcc}
\hline Jenis kelamin & Frekuensi & Persentase \% \\
\hline Laki-laki & $\mathbf{4 4}$ & $\mathbf{1 7}$ \\
Perempuan & $\mathbf{2 1 4}$ & $\mathbf{8 3}$ \\
\hline Jumlah & $\mathbf{2 5 8}$ & $\mathbf{1 0 0}$
\end{tabular}

b. Usia

Tabel 3

Distribusi Usia Responden di Kampus STIKes Dharma Husada Bandung

Tahun 2020

\begin{tabular}{lcc}
\hline Umur & Frekuensi & Persentase \% \\
\hline$<20$ Tahun & 31 & 12 \\
20-35 Tahun & 182 & 71 \\
$>35-50$ Tahun & 39 & 15 \\
$>$ 50 Tahun & 6 & 2 \\
\hline Jumlah & 258 & 100 \\
\hline
\end{tabular}


c. Status

Tabel 4

Distribusi Status Responden di Kampus STIKes Dharma Husada Bandung Tahun 2020

\begin{tabular}{lcc}
\hline Status & Frekuensi & Persentase \% \\
\hline Dosen & 29 & 11 \\
Staff & 17 & 7 \\
Mahasiswa Prodi & 60 & 23 \\
Kesehatan masyarakat & 40 & 16 \\
Mahasiswa Prodi Sarjana Keperawatan & 28 & 11 \\
Mahasiswa Prodi Profersi Ners & 19 & 7 \\
Mahasiswa Prodi D3 Keperawatan & 16 & 6 \\
Mahasiswa Prodi Kebidanan & 36 & 14 \\
Mahasiswa Prodi D3 Refraksi Optisi & 14 & 5 \\
Mahasiswa Prodi Magister Terapan Kebidanan & & \\
\hline Jumlah & 258 & 100 \\
\hline
\end{tabular}

d. Jenis Gadget

Tabel 5

Distribusi Responden Jenis Gadget di Kampus STIKes Dharma Husada Bandung Tahun 2020

\begin{tabular}{lcc}
\hline Jenis Gadget & Frekuensi & Persentase \% \\
\hline Laptop & 10 & 4 \\
Mobile Phone & 134 & 52 \\
Mobile Phone,laptop & 107 & 41 \\
Mobile,Tablet,laptop & 6 & 2 \\
Tablet & 1 & 1 \\
\hline Jumlah & 258 & 100 \\
\hline
\end{tabular}

e. Durasi Penggunaan Mobile Phone

Tabel 6

Distribusi Responden Durasi Penggunaan

Mobile Phone di Kampus STIKes Dharma

Husada Bandung Tahun 2020

\begin{tabular}{lcc}
\hline Durasi & Frekuensi & Persentase \% \\
\hline 1-3 jam & 43 & 17 \\
$>$ 2-3 jam & 1 & 1 \\
$>3-5$ jam & 76 & 29 \\
$>5$ jam & 138 & 53 \\
& & \\
\hline Jumlah & 258 & 100 \\
\hline
\end{tabular}

f. Durasi Penggunaan Tablet atau Laptop

Tabel 7

Distribusi Responden Durasi Penggunaan

Tablet atau Laptop di Kampus STIKes

Dharma Husada Bandung Tahun 2020

\begin{tabular}{|l|c|c|}
\hline \multicolumn{1}{|c|}{ Durasi $h$} & Frekuensi & Persentase $(\%)$ \\
\hline$<1$ jam & 25 & 10 \\
1-2 jam & 63 & 24 \\
$>$ 2-3 jam & 65 & 25 \\
$>3-5$ jam & 74 & 29 \\
5 jam & 31 & 12 \\
\hline Jumlah & 258 & 100 \\
\hline
\end{tabular}

g. Jarak Penggunaan Mobile Phone

Tabel 8

Distribusi Responden Jarak penggunaan

Mobile Phone di Kampus STIKes Dharma

Husada Bandung Tahun 2020

\begin{tabular}{lcc}
\hline $\begin{array}{c}\text { Jarak Penggunaan } \\
\text { Mobile Phone }\end{array}$ & Frekuensi & $\begin{array}{c}\text { Persentase } \\
\%\end{array}$ \\
\hline $10 \mathrm{~cm}$ & 54 & 21 \\
$20 \mathrm{~cm}$ & 93 & 36 \\
$30 \mathrm{~cm}$ & 90 & 35 \\
$>30 \mathrm{~cm}$ & 21 & 8 \\
\hline Jumlah & 258 & 100 \\
\hline
\end{tabular}


h. Jarak Penggunaan Tablet atau Laptop

Tabel 9

Distribusi Responden Jarak penggunaan Tablet atau Laptop di Kampus STIKes Dharma Husada Bandung Tahun 2020

\begin{tabular}{lcc}
\hline $\begin{array}{l}\text { Jarak Penggunaan } \\
\text { Tablet atau Laptop }\end{array}$ & Frekuensi & $\begin{array}{c}\text { ersentase } \\
\%\end{array}$ \\
\hline$>30 \mathrm{~cm}$ & 81 & 31 \\
$10 \mathrm{~cm}$ & 17 & 7 \\
$20 \mathrm{~cm}$ & 55 & 21 \\
$30 \mathrm{~cm}$ & 105 & 41 \\
\hline Jumlah & 258 & 100 \\
\hline
\end{tabular}

i. Keluhan Kelelahan Mata

Tabel 10

Distribusi Keluhan Kelelahan Mata

Responden di Kampus STIKes Dharma Husada Bandung Tahun 2020

\begin{tabular}{lcc}
\hline $\begin{array}{l}\text { Keluhan Kelelahan } \\
\text { mata }\end{array}$ & Frekuensi & $\begin{array}{c}\text { Persentase } \\
\%\end{array}$ \\
\hline $\begin{array}{l}\text { Memiliki keluhan } \\
\text { mata }\end{array}$ & 236 & 93 \\
$\begin{array}{l}\text { Tidak memiliki } \\
\text { keluhan. }\end{array}$ & 22 & 9 \\
\hline Jumlah & 258 & 100 \\
\hline
\end{tabular}

Tabel 11

Distribusi Keluhan Kelelahan Mata

Berdasarkan Jenis Kelamin Wanita Responden Civitas STIKes Dharma Husada Bandung Tahun 2020

\begin{tabular}{lcc}
\hline $\begin{array}{l}\text { Keluhan } \\
\text { Kelelahan mata }\end{array}$ & Frekuensi & $\begin{array}{c}\text { Persentase } \\
\%\end{array}$ \\
\hline $\begin{array}{l}\text { Wanita dengan } \\
\text { keluhan mata }\end{array}$ & 195 & 91 \\
$\begin{array}{l}\text { Wanita Tidak } \\
\text { memiliki keluhan } \\
\text { mata }\end{array}$ & 19 & 9 \\
\hline Jumlah & 214 & 100 \\
\hline
\end{tabular}

Tabel 12

Distribusi Keluhan Kelelahan Mata Menurut Jenis Kelamin Pria Responden Civitas STIKes Dharma Husada Bandung Tahun 2020

\begin{tabular}{lcc}
\hline $\begin{array}{l}\text { Keluhan Kelelahan } \\
\text { mata }\end{array}$ & Frekuensi & $\begin{array}{c}\text { Persentase } \\
\%\end{array}$ \\
\hline $\begin{array}{l}\text { Pria dengan keluhan } \\
\text { mata }\end{array}$ & 41 & 93 \\
$\begin{array}{l}\text { Pria Tidak memiliki } \\
\text { keluhan mata }\end{array}$ & 3 & 7 \\
\hline Jumlah & 44 & 100 \\
\hline
\end{tabular}

\section{B. PEMBAHASAN}

\section{Karakteristik Responden}

\section{Jenis Kelamin}

Jenis kelamin merupakan faktor resiko eyestrain atau kelelahan mata. dimana kelelahan mata lebih beresiko dan lebih sering pada perempuan. Seiring bertambahnya usia, hormon esterogen dan antiandrogen pada wanita akan meningkat. kedua hormon tersebut akan menekan sekresi dari air mata, sehingga lapisan air mata pada perempuan cenderung menipis dibandingkan laki-laki. Penipisan air mata ini akan mengakibatkan mata cenderung mengalami kelelahan mata saat menggunakan gadget atau komputer (Versura \& Campos 2005).

Selain itu ada perbedaan fisiologis yang menyebabkan perempuan lebih rentan terhadap penyakit dan memiliki tingkat stres yang lebih tinggi. Perempuan cenderung lebih teliti dan telaten dalam bekerja sehingga mereka akan benar-benar memusatkan perhatian pada pekerjaan yang dihadapi untuk mengurangi kesalahan bekerja (Kurmasela, 2013).

Namun, pada penelitian ini didapatkan bahwa jenis kelamin laki-laki lebih banyak mengalami 
keluhan kelelahan mata dibandingkan perempuan yaitu sebanyak $94 \%$.

\section{Usia}

Usia adalah salah satu faktor risiko terjadinya eyestrain atau kelelahan mata. Menurut Ilyas 2015, semakin bertambahnya usia maka lensa mata akan mengalami kemunduran kemampuan untuk mencembung atau berkurangnya daya untuk akomodasi. Menurut Murtopo dan Sarimurni 2005, faktor usia berhubungan dengan penglihatan seseorang dalam lingkungan kerja, pertambahan umur dapat menyebabkan pembentukan serabut lamel secara terusmenerus, hingga mengakibatkan lensa bertambah besar dan berkurang elastisitasnya. Di usia 20 tahun, manusia pada umumnya dapat melihat

objek dengan jelas, sedangkan pada usia 45 tahun kebutuhan terhadap cahaya empat kali lebih besar (Guyton dan Hall, 2006).

Pada usia ini, seseorang akan mengalami kesulitan dalam memfokuskan penglihatannya yang disebabkan oleh presbiopia. Hal ini merupakan sesuatu yang normal karena disebabkan oleh lensa di dalam mata. Menginjak usia 50 tahun, presbiopia akan semakin terasa dampaknya. Seseorang akan membutuhkan kacamata dengan lensa yang lebih tajam dalam frekuensi yang sering. Seseorang juga akan membutuhkan lebih dari satu lensa, yaitu lensa yang digunakan untuk kegiatan normal dan lensa yang dapat digunakan saat mengoperasikan komputer agar terasa lebih nyaman (Heiting, 2014).

Pada usia 60 tahun, kebutuhan cahaya yang diperlukan untuk melihat jauh lebih besar dibandingkan usia 45 tahun karena pada usia 4550 tahun daya akomodasi mata berkurang (Guyton dan Hall, 2006).

\section{Durasi penggunaan gadget}

Saat menatap layar gadget dalam waktu lama dan terus menerus dengan frekuensi mengedip yang rendah dapat menyebabkan mata mengalami penguapan berlebihan sehingga mata menjadi kering. Apabila mata kekurangan air mata maka dapat menyebabkan mata kekurangan nutrisi dan oksigen. Dalam waktu yang lama kondisi seperti ini dapat menyebabkan gangguan penglihatan menetap.

Hasil penelitian berdasarkan durasi penggunaan gadget berjenis Mobile Phone didapatkan rata-rata yaitu 5 jam/hari. Sedangkan untuk gadget berjenis Tablet atau Laptop didapatkan rata-rata $>3-5$ jam/hari.

Seorang ahli dari SUNY State College of Optometry di kota New York bernama Dr. Mark Rosenfield mengatakan jika seseorang terlalu lama membaca teks, pesan, atau browsing dengan menggunakan gadget, laptop, dan tablet maka akan membuat mata kering. Akibatnya penglihatan menjadi kabur (Ishidharmanjaya dan Agency, 2014).

Untuk mengurangi resiko terjadinya kelelahan mata saat menatap layar gadget, istirahatkanlah mata anda dengan aturan 20-20-20 artinya : 
setiap 20 menit, lihat sesuatu berjarak 20 kaki selama setidaknya 20 detik.

\section{Jarak Pandang gadget}

Mata melakukan kegiatan akomodasi pada saat melihat objek, baik dengan jarak jauh maupun jarak dekat. Hal ini bertujuan agar mata dapat melihat objek dengan jelas. Kegiatan akomodasi yang dilakukan oleh otot mata ini dapat menyebabkan kelelahan mata. Kejadian ini dapat terjadi sebagai akibat dari akomodasi yang tidak efektif hasil dari otot mata yang lemah dan tidak stabil (Djua, 2015).

Menjaga jarak pandang pada saat menggunakan gadget merupakan salah satu hal yang penting untuk menjaga kesehatan indera penglihatan. untuk melihat suatu objek dengan jelas mata harus melakukan kegiatan akomodasi. Apabila melihat objek dalam jarak yang jauh maupun jarak yang terlalu dekat maka mata akan berakomodasi (Djua, 2015). Sebuah penelitian menunjukkan bahwa ketika individu membaca pesan teks atau browsing di internet melalui smartphone atau tablet cenderung memegang gadget ini lebih dekat dengan mata, sehingga otot-otot pada mata cenderung bekerja lebih keras. Kerja mata saat menggunaakan gadget adalah memfokuskan dengan teks pada smartphone ataupun tablet hal itu jika dibiarkan akan menyebabkan sakit kepala dan tegang di daerah kelopak mata (Ishidharmanjaya dan Agency, 2014)
Selain itu gejala yang dapat timbul adalah penglihatan ganda, mata kering, sensitif terhadap cahaya dan sakit kepala (Wilson, 2015).

Namun, Anda dapat mengurangi gejala kondisi ini dengan berbagai langkah mudah dan efektif, seperti : menatap layar gadget dengan jarak $30 \mathrm{~cm}$, istirahatkan mata dengan metode 20-2020, sering mengedipkan mata, dan mengatur tingkat intensitas pencahayaan pada layar gadget.

\section{KESIMPULAN}

Dari hasil penelitian diketahui bahwa secara umum dinilai belum baik terbukti dengan hasil kuesioner terhadap 258 orang responden pada Tabel.4.4 Durasi penggunaan gadget $>5$ jam, sebanyak 138 orang (53\%). Tabel. 4.6 Durasi penggunaan tablet dan laptop >3-5jam sebanyak 74 orang (29\%). Tabel 4.7 Jarak Penggunaan Gadget 20cm sebanyak 93 orang (36\%). Tabel 4.8 Jarak Penggunaan Tablet dan laptop $30 \mathrm{~cm}$ sebanyak 105 orang (41\%). Tabel 4.9 Responden dengan Keluhan Kelelahan Mata sebanyak 236 orang (93\%).

Maka diperoleh hasil berdasarkan distribusi jarak, durasi, dan keluhan kelelahan mata sebagai berikut :

a. Berdasarkan distribusi jarak penggunaan gadget berjenis Mobile Phone terbanyak yaitu pada jarak $20 \mathrm{~cm}$ dengan jumlah 93 orang $(36 \%)$.

b. Berdasarkan distribusi jarak penggunaan gadget berjenis tablet atau laptop terbanyak 
yaitu pada jarak 30cm dengan jumlah 105 orang $(41 \%)$.

c. Berdasarkan distribusi durasi penggunaan Mobile Phone pada durasi $>5$ jam sebanyak 138 orang $(53 \%)$.

d. Berdasarkan distribusi durasi penggunaan Tablet dan Laptop pada durasi >3-5 jam sebanyak 74 orang (29\%).

e. Berdasarkan distribusi responden dengan keluhan kelelahan mata terdapat 236 orang (94\%) mengalami keluhan kelelahan mata.

\section{DAFTAR PUSTAKA}

Ananda, S.N., Dinata, K. (2015). Hubungan Intensitas Pencahayaan dengan Keluhan Subjektif Kelelahan Mata pada Mahasiswa Semester II Program Studi Pendidikan Dokter Fakultas Kedokteran Universitas Udayana.Skripsi, tidak dipublikasikan, Program Studi Pendidikan Dokter Fakultas Kedokteran Universitas Udayana.

Anggraini N, Wahyuni A, Awaluddin. 2017. Faktor yang berhubungan dengan keluhan kelelahan mata karyawan di PT Pertamina (persero) mor vii Makassar [Skripsi]. Makassar: Universitas Hasanuddin.

Heiting, Gary. 2014. How Your Vision Changes as You Age. Tersedia di http://www.allaboutvision.com/over60/vis ion-changes.htm diakses pada 5 Mei 2016

https://www.academia.edu/1836054/2.1_Profil_ Tempat_Kerja_Praktek_2.1._1_Sejarah _STIKes_Dharma_Husada_Bandung?em ail work card=thumbnail

Ihsan, S. (2011). Gambaran Tingkat Pengetahuan Dan Sikap Siswa Sekolah Dasar Islam Cireundeu Kelas 5 dan Terhadap Miopia dan Faktor Yang Mempengaruhiny
Djua, N. (2015). Gambaran Faktor-Faktor Yang Mempengaruhi Progresivitas Penderita Miopia di Poliklinik Mata RSUD Prof. DR. H. Aloei Saboe. Skripsi, tidak dipublikasikan, Gorontalo, Universitas Negeri Gorontalo, Indonesia.

Fitri, T. I. (2017). HUBUNGAN LAMA PENGGUNAAN DAN JARAK PANDANG GADGET . 7.

GANIE, M. A. (2019). Durasi, jarak, kelelahan mata, smartphone. HUBUNGAN JARAK DAN DURASI PEMAKAIAN SMARTPHONE DENGAN KELUHAN KELELAHAN MATA PADA MAHASISWA FAKULTAS KEDOKTERAN UNIVERSITAS LAMPUNG , 12-15

.Guyton, Arthur C dan Hall, John E.. 2006. Medical Physiology. Eleventh Edition.

Pennsylvania: Elsevier Saunders

Handrawan, N. (2014). Dampak penggunaan gadget pada kesehatan mata http://www/combiphar.com/id/healtyliving/dampak-penggunaangadget-padakesehatan-mata, diperoleh 12 November 2016.

Hendrawan. (2016). Dampak penggunaan gadget pada kesehatan mata. http://www/combiphar.com/id/healtyliving/dampak-penggunaangadget-padakesehatan-mata,.

Ilyas, S. (2013). Ilmu Penyakit Mata. Jakarta: Fakultas Kedokteran Universitas Indonesia.

Ilyas, S. (2015). Ilmu Penyakit Mata. Jakarta. Balai Penerbit FK UI. 11.

Ishidharmanjaya dan Agency. (2014). Bila Si Kecil Bermain Gadget. Yogyakarta, Electronic book (Ebook).

Juneti, Bebasari E, Nukman E. 2015. Gambaran Faktor-Faktor yang Mempengaruhi Gangguan Tajam Penglihatan pada Anak Sekolah Dasar Kelas V dan Kelas VI di SDN 017 Bukit Raya Pekanbaru Tahun 2014. JOM FK, Vol II, No 2. 
Kurmasela, Grace P, dkk. 2013. Hubungan Waktu Penggunaan Laptop dengan Keluhan Penglihatan pada Mahasiswa Fakultas Kedokteran Universitas Sam Ratulangi. Jurnal e-Biomedik, 1(1).

LAMPUNG, H. J. (2019). durasi, jarak, kelelahan mata, smartphone. 1.

Mangoenprasodjo (2005). Mata Indah, Mata Sehat. Yogyakarta: Thinkfresh, Trisna Ika Fitri 2017, Suprayitno HUBUNGAN LAMA PENGGUNAAN DAN JARAK PANDANG GADGET DENGAN KETAJAMAN PENGLIHATAN PADA ANAK SEKOLAH DASAR KELAS 2 DAN 3 DI SDN 027 KOTA SAMARINDA

Murtopo, I dan Sarimurni. 2005. Pengaruh Radiasi Laya Komputer Terhadap Kemampuan Daya Akomodasi Mata Mahasiswa Pengguna Komputer di Universitas Muhammadiyah Surakarta. Jurnal Penelitian Sains dan Teknologi. Vol.6, No.2, Hal. 153-163

Muhammad Azzibaginda Ganie, R. H. (2019). HUBUNGAN JARAK DAN DURASI PEMAKAIAN SMARTPHONE DENGAN KELUHAN KELELAHAN MATA PADA MAHASISWA FAKULTAS KEDOKTERAN UNIVERSITAS LAMPUNG. durasi, jarak, kelelahan mata, smartphone, 1.

Nursalam. (2016). Pengukuran pengetahuan . 12.
Porotu'o, Joseph, Sondakh. (2014). FaktorFaktor yang Berhubungan dengan Ketajaman Penglihatan Pada Pelajar Sekolah Dasar Katolik Santa Theresia 02 Kota Manado. Jurnal Kesehatan Masyarakat, 4, (1).

Trisna Ika Fitri1, S. (2017). HUBUNGAN LAMA PENGGUNAAN DAN JARAK PANDANG GADGET DENGAN KETAJAMAN PENGLIHATAN PADA ANAK SEKOLAH DASAR KELAS 2. INTISARI, 4-5.

Trisna Ika Fitri1, Suprayitno. (2017). UBUNGAN LAMA PENGGUNAAN DAN JARAK PANDANG GADGET DENGAN KETAJAMAN PENGLIHATAN PADA ANAK SEKOLAH DASAR KELAS 2 DAN 3 DI SDN 027 KOTA SAMARIND. Lama Penggunaan Gadget, Jarak Pandang Gadget, Ketajaman Penglihatan, Anak Sekolah Dasar. , 1-6.

Versura, Piera dan Campos, EC. 2005. Menopause and Dry Eye. A Possible Relationship. Gynecol Endocrinol, 20(5), 289-298.

Wilson S. 2015. Eyestrain. Michigan: University of Michigan Health System.

WULUR, F. C. (2017). TINGKAT PENGETAHUAN SISWA-SISWI TENTANG KESEHATAN. tingkat pengetahuan, kesehatan mata, 20-22. 